\title{
Influence of Pesticides Selection Pressure on Protein Banding Patterns of the Two Spotted Spider Mite Tetranychus urticae Koch by SDS-PAGE
}

\author{
G. A. EL Kady ; S. M. M. Ismail*; M. S. Salman ${ }^{* *}$ and Y. M. Ahmed* \\ *Plant Protection Dept., Faculty of Agric., Suez Canal University, Ismialia, Egypt \\ "Plant Protection, Agriculture Research Station, Ismailia, Egypt
}

\begin{abstract}
The aim of the present study was to investigate the effect of three pesticides selection pressure on the protein banding of the two-spotted spider mite Tetranychus urticae Koch by SDS-PAG electrophoresis comparing. In this experiment, four batches of mite colonies reared for nine months away from any pesticide contamination were exposed for selection pressure of the tested pesticides. The first batch was subjected to successive selection with chlorfenapyr, the second patch was subjected to repeated selection of fenpyroximate, the third one for repeated selection of hexythiazox, whereas the 4th patch was left without any pesticide treatment as a check. Selection pressure was carried out at LC50 level of each of the tested toxicant. The selection was studied for 12 generations to follow up the development of resistance and the resistance ratio (RR) values were calculated. The highest RR value of F12 selected generation was for Fenpyroximate (14.32) followed by 12.06 for chlorfenapyr, while the lowest value was obtained by hexythiazox (4.22). Comparing the protein banding pattern of chlorfenapyr fenpyroximate, and hexythiazox resistant strains with the susceptible one, it was found that the protein bands with MW (54 and 36 KD) appeared only in susceptible strain, while disappeared in the other tested resistant strains of the two-spotted spider mite $T$. urticae. The protein band with MW 44 KD was appeared only in Hexythiazox resistant strain. The protein bands with MW 53 and 34 KD were only found in fenpyroximate resistant strain of $T$. urticae, whereas such bands were not found in the other strains. The protein bands pattern with MW 146, 35 and $31 \mathrm{KD}$ were found only in hexythiazox and chlorfenapyr resistant strains of T. urticae. Such result may indicate that the mechanism of resistance strains is similar for both strains.
\end{abstract}

Key Words: Tetranychus urticae, SDS-PAGE, Pesticides pressure, Hexythiazox, Fenpyroximate, Chlorfenapyr.

\section{INTRODUCTION}

The two spotted spider mite Tetranychus urticae Koch is an important economically pests infesting many crops specially vegetables. The wide use of chemical compounds caused many problems such as pulation and chemical resistance endangering human health and wealth.

Molecular studies and protein electrophoresis have been used for the detection of genetic polymorphism to mites (Lewontin, 1991; Osakabe \& Komazaki 1996; Navajas \& Fenton 2000 and Smrz, 2000). Electrophoretic techniques used to study a wide range of problems, such as species identification (Avanzati et al., 1994; Enohara \& Amano, 1996 and Goka and Takafuji, 1997), genetic divergence between population (Navajas et al. 2000), feeding preferences of predatory mites (Solomon et al., 1985 ) and paternity analysis (Yasui 1997).

The aim of this study was to investigate the effect of selection pressure with some pesticides on the protein banding patterns from chlorfenapyr fenpyroximate, and hexythiazox resistant strains of the two-spotted spider mite $T$. urticae by SDS-PAGE electrophoresis comparing with protein banding pattern of the susceptible strain.

\section{MATERIALS AND METHODS}

\section{Chemicals Used}

1. Growth regulator: Hexythiazox (Maccomite 10\% WP)

trans-5-(4-chlorophenyl)- $N$-cyclohexyl-4-methyl -2-oxothiazolidine-3-carboxamide

2. Pyrrole compound: Chlorfenapyr (Challenger $36 \% \mathrm{SC})$

4-bromo-2-(4-chlorophenyl)-1-(ethoxymethyl)-5(trifluoromethyl)-1H-pyrrole-3-carbonitrile

3. Acaricide: Fenpyroximate (Ortus 5\% SC) 1,1-dimethylethyl4-[(E)-[(1,3-dimethyl-5-phenoxy -1H-pyrazol-4-yl) methylene] amino] oxy] methyl] benzoate

\section{Rearing Mites under Pesticide Selection Pressure}

This work aims to study the rate of development of resistance phenomenon to three selected pesticides, chlorfenapyr, fenpyroximate and hexythiazox. Therefore, four batches of mite colonies which had been reared for nine months away from any pesticide contamination were reared for selection pressure of the tested pesticides. The first batch was subjected to successive selection with chlorfenapyr, the second batch with fenpyroximate, the third one with hexythiazox, whereas the $4^{\text {th }}$ was left free from any pesticide treatment as a check. 
The selection pressure was carried out by dipping sweet potato cuttings each holding six leaves in water-dilution of the tested toxicant for 5 seconds. The treated cuttings were left for solvent evaporation. The old treated leaves were placed over the new treated ones to allow immigration of the mites to the later leaves. Selection pressure was carried out at $\mathrm{LC}_{50}$ level of each of the tested toxicant. The selection was studied for 12 generations to follow up the development of resistance.

For studying the level of resistance in the three selected strains, toxicity lines of the inducer against the adult females were established every generation using leaf disc residue film technique. All the results of the selected strains were compared with those of the laboratory susceptible strain.

SDS-Polyacrylamide Gel Electrophoresis of Protein

Sodium dodecyl sulfate polyacrylamide gel electrophoresis SDS-PAGE was used to separate the protein of selection pressure on the protein banding patterns from fenpyroximate, chlorfenapyr and hexythiazox resistant strains of the two-spotted spider mite $T$. urticae comparing with protein baning pattern of susceptible strain.

The protein contents were determined using the Lowery method (Lowery et al, 1951). An aliquot contain $100 \mu \mathrm{g}$ protein was placed in a $2 \mathrm{x}$ volume of sample buffer containing 10\% glycerol, 5\% 2-mercaptoethanol, 2\% SDS, 0.0725 Tris-HCl buffer (pH 6.8) and $0.01 \%$ bromophenol blue. Sample and the mixture tissue were heated in boiling water for 10 minutes.

An aliquot containing approximately $30 \mu \mathrm{g}$ of protein of such preparation was loaded onto acrylamide gel and electrophoresis was carried out until the bromophenol blue track reached the bottom of the gel at 5 to $10 \mathrm{~mA}$ on a vertical plate gel containing $12.5 \%$ acrylamide separating gel and $1.0 \mathrm{~cm}$ of $5 \%$ acrylamide stacking gel. Gel and electrode buffer $(\mathrm{pH} 8.3)$ were prepared according to Laemmli (1970) and King \& Laemmli (1971). The molecular weights of the protein bands on the SDS gels were determined by comparing the nobilities of the protein with proteins of known molecular weight according to Weber and Osborn (1969).

Following electrophoresis, the gels were fixed in $25 \%$ isopropanol and $10 \%$ acetic acid for 30 minutes. Protein bands were stained with a solution of $25 \%$ methanol, $10 \%$ acetic acid and $0.025 \%$ coomassie blue R. 250 for several hours, and later distained by shacking in $10 \%$ acetic acid the gels were placed on several layers of filter papers and slowly dried under vacuum. Data were analyzed by image analysis system to show the differentiations between species using protein marker as a stander.

\section{RESULTS AND DISCUSSION}

\section{Developmental Pressure of Pesticides Selection on the Susceptibility of the Two-Spotted Spider Mite T. urticae Adult Females \\ Effect of Fenpyroximate}

Data in table (1) showed the building up of the resistance to fenpyroximate in the laboratory strain of the two spotted spider mite during 12 generations. The results revealed that $\mathrm{LC}_{50}$ value generally increased from $2.19 \mathrm{ppm}$ in parent generation to $11.96 \mathrm{ppm}$ in the $6^{\text {th }}$ generation, while in the $9^{\text {th }}$ generation increased to $21.52 \mathrm{ppm}$ and reached $31.5 \mathrm{ppm}$ in the $12^{\text {th }}$ generation. Such result indicated that the resistance ratio (RR) increased to 14.32 folds in $\mathrm{F} 12$ selected generation at $\mathrm{LC}_{50}$.

Concerning slope values F1 line had the flattest regression line (slope $=1.66$ ), while F12 was the steepest regression line $($ slope $=1.38)$. This might be related to the increasing in homogenecity in F12 which was more than in the other selected generation.

The present data coincide with the results of Ioriatti et al. (2000) who used resistant ratios to evaluate the level of resistance; resistance was detected with discriminating doses. Resistance to

Table (1): Effect of three pesticides selection on the susceptibility of adult females of two-spotted spider mite $T$. urticae.

\begin{tabular}{ccccccc}
\hline Pesticides & \multicolumn{2}{c}{ Chlorfenapyr } & \multicolumn{2}{c}{ Fenpyroximate } & \multicolumn{2}{c}{ Hexythiazox } \\
\hline Generations & LC $_{50}$ & R.r. & LC $_{50}$ & R.r. $^{*}$ & LC $_{50}$ & R.r. $^{*}$ \\
\hline Susceptible & 1.59 & - & 2.19 & - & 5.06 & - \\
\hline 1 & 1.69 & 1.06 & 2.41 & 1.20 & 5.08 & 1.01 \\
\hline 2 & 1.71 & 1.08 & 2.64 & 1.20 & 5.50 & 1.09 \\
\hline 3 & 3.07 & 1.93 & 2.74 & 1.25 & 5.83 & 1.15 \\
\hline 4 & 3.61 & 2.27 & 10.26 & 4.76 & 5.33 & 1.05 \\
\hline 5 & 4.85 & 3.05 & 11.89 & 5.41 & 5.69 & 1.13 \\
\hline 6 & 4.82 & 3.03 & 11.69 & 5.44 & 6.25 & 1.24 \\
\hline 7 & 9.23 & 5.81 & 16.90 & 7.69 & 6.62 & 1.31 \\
\hline 8 & 9.05 & 5.98 & 17.17 & 7.81 & 10.74 & 2.12 \\
\hline 9 & 11.79 & 7.42 & 21.52 & 9.79 & 10.98 & 2.17 \\
\hline 10 & 14.96 & 9.41 & 23.16 & 10.53 & 19.79 & 3.91 \\
\hline 11 & 18.23 & 11.47 & 31.02 & 14.11 & 20.73 & 4.1 \\
\hline 12 & 19.18 & 12.06 & 31.50 & 14.33 & 21.34 & 4.22 \\
\hline$* . r .6$
\end{tabular}

* R.r. = Resistant ratio 
fenpyroximate and propargite results widespread in all apple orchards investigated. No evidence of cross resistance between fenpyroximate and the other two METI (Mitochondrial Electron Transport Inhibitor) has been found in this study.

\section{Effect of Chlorfenapyr}

Data in table (1) showed the building up of the resistance to chlorfenapyr in the laboratory strain of two spotted spider mite during 12 generations. The result indicated that $\mathrm{LC}_{50}$ value generally increased from $1.59 \mathrm{ppm}$ in parent generation to $4.82 \mathrm{ppm}$ in the $6^{\text {th }}$ generation, while in the $9^{\text {th }}$ generation it increased to $11.79 \mathrm{ppm}$ and reached $19.18 \mathrm{ppm}$ in the $12^{\text {th }}$ generation. Such results indicated that the resistance ratio (RR) increased to 12.06 folds at F12 selected generation at $\mathrm{LC}_{50}$.

Concerning slope values, F1 line had the flattest regression line (slope $=1.73$ ), while F12 was the steepest regression line (slope $=1.12$ ). This might be due to increase homogenecity in F12 which was more than in the other selected generation.

\section{Effect of Hexythiazox}

Data in Table (1) showed building up of the resistance to hexythiazox in the laboratory strain of two spotted spider mite during 12 generations. The results indicated that $\mathrm{LC}_{50}$ value generally increased from $5.06 \mathrm{ppm}$ in parent generation to $6.62 \mathrm{ppm}$ in the $7^{\text {th }}$ generation, while in the $8^{\text {th }}$ generation it increased to $10.74 \mathrm{ppm}$ and reached $21.34 \mathrm{ppm}$ in the $12^{\text {th }}$ generation. Such results indicated that the resistance ratio (RR) increased to 4.22 folds in F12 selected generation at $\mathrm{LC}_{50}$.

Concerning slope values, F1 line had the flattest regression line $($ Slope $=1.34$ ), while F12 was the steepest regression line (slope $=1.27$ ). This might be correlated with the increasing in homogenecity in F12 which was more than in the other selected generation. The present data are coincided with the results of Flexner et al. (1995) who found that $\mathrm{LC}_{50} \mathrm{~S}$ in the consecutive hexythiazox program increased after the $5^{\text {th }}$ generation.

Influence of Pesticides Selection Pressure on Protein Banding Patterns of the Two-Spotted Spider Mite $T$. urticae by SDS-PAG Electrophoresis

The protein banding patterns in this technique were arranged according to their variable molecular weight. The protein banding patterns differences of those resistant strains and susceptible strain were examined by using SDS-PAGE electrophoresis technique (Figs $1 \&$ 2). The results presented in

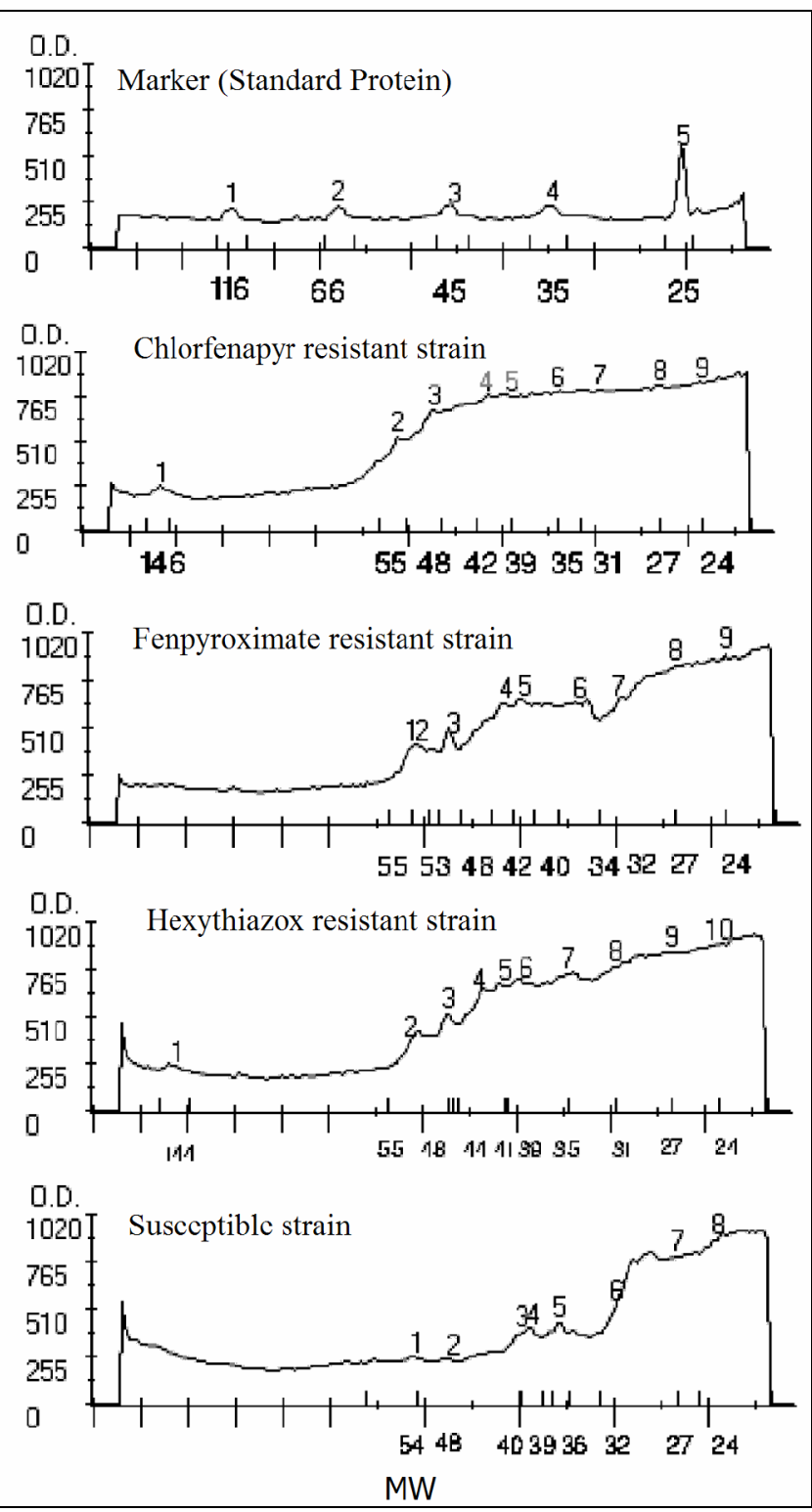

Fig. (1): Densitometric analysis of Silver stained protein bands.

MW $=$ Molecular weight $\quad$ O.D. $=$ Optical density

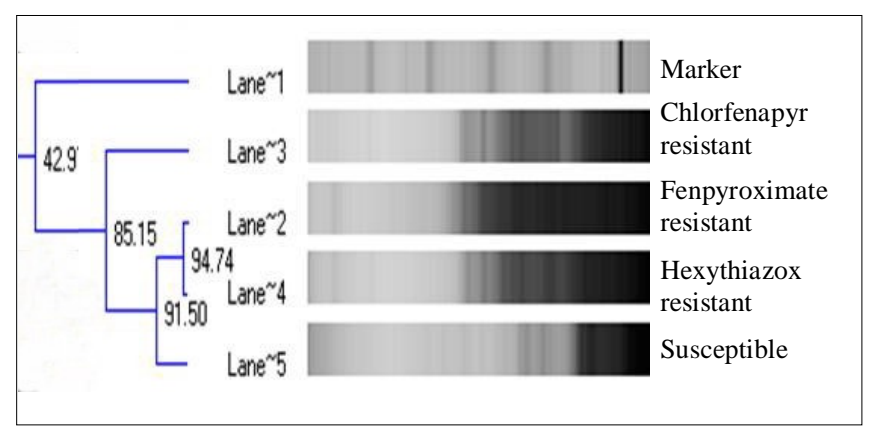

Fig. (2): Cluster analysis showing the similarity polymorphism of protein banding patterns obtained by SDS-PAGE. 
Table (2): Protein banding patterns obtained by SDS-PAGE from Marker (Standard protein), Chlorfenapyr, Fenpyroximate, Hexythiazoxresistant strains and susceptible strain of Tetranychus urticae as total amount \%.

Protein banding patterns as \% Amt

\begin{tabular}{|c|c|c|c|c|}
\hline $\begin{array}{l}\text { MW } \\
\text { KDa }\end{array}$ & 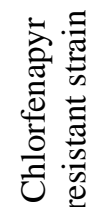 & 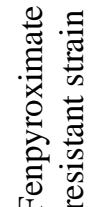 & 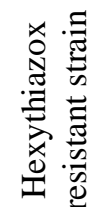 & 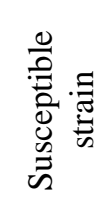 \\
\hline
\end{tabular}

\begin{tabular}{ccccc}
\hline 146 & 0.72 & 0.00 & 0.89 & 0.00 \\
\hline 55 & 1.47 & 2.31 & 32.71 & 0.00 \\
\hline 54 & 0.00 & 0.00 & 0.00 & 5.63 \\
\hline 53 & 0.00 & 4.51 & 0.00 & 0.00 \\
\hline 48 & 2.82 & 3.03 & 0.30 & 17.95 \\
\hline 44 & 0.00 & 0.00 & 3.67 & 0.00 \\
\hline 42 & 29.37 & 4.23 & 0.00 & 0.00 \\
\hline 41 & 0.00 & 0.00 & 0.20 & 0.00 \\
\hline 40 & 0.00 & 4.46 & 0.00 & 0.40 \\
\hline 39 & 25.82 & 0.00 & 25.67 & 4.20 \\
\hline 36 & 0.00 & 0.00 & 0.00 & 3.12 \\
\hline 35 & 20.99 & 0.00 & 20.41 & 0.00 \\
\hline 34 & 0.00 & 8.23 & 0.00 & 0.00 \\
\hline 32 & 0.00 & 45.40 & 0.00 & 31.98 \\
\hline 31 & 8.48 & 0.00 & 5.75 & 0.00 \\
\hline 27 & 4.64 & 13.84 & 5.04 & 7.76 \\
\hline 24 & 5.42 & 13.99 & 5.37 & 28.96 \\
\hline
\end{tabular}

M.W. = Molecular weight
Table (4): Protein banding patterns obtained by SDS-PAGE from marker (standard protein), Chlorfenapyr, Fenpyroximate, Hexythiazox resistant strains and susceptible strain of Tetranychus urticae.

\begin{tabular}{|c|c|c|c|c|}
\hline \multirow[b]{2}{*}{$\begin{array}{l}\text { MW } \\
\text { KDa }\end{array}$} & \multicolumn{4}{|c|}{$\begin{array}{l}\text { Protein banding patterns of obtained SDS } \\
\text { PAGE from }\end{array}$} \\
\hline & 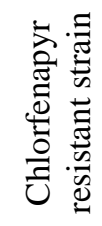 & 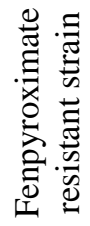 & 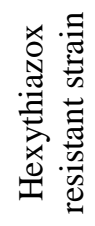 & 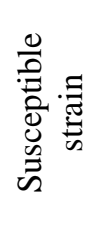 \\
\hline 146 & + & - & + & - \\
\hline 55 & + & + & + & - \\
\hline 54 & - & - & - & + \\
\hline 53 & - & + & - & - \\
\hline 48 & + & + & + & + \\
\hline 44 & - & - & + & - \\
\hline 42 & + & + & - & - \\
\hline 41 & - & - & + & + \\
\hline 40 & - & + & - & + \\
\hline 39 & + & - & + & + \\
\hline 36 & - & - & - & + \\
\hline 35 & + & - & + & - \\
\hline 34 & - & + & - & - \\
\hline 32 & - & + & - & + \\
\hline 31 & + & - & + & - \\
\hline 27 & + & + & + & + \\
\hline 24 & + & + & + & + \\
\hline
\end{tabular}

Table (3): Protein banding patterns obtained by SDS-PAGE from Marker (Standard protein), Chlorfenapyr,

Fenpyroximate, Hexythiazox-resistant strains and susceptible strain of Tetranychus urticae as peak area.

\begin{tabular}{|c|c|c|c|c|c|c|c|}
\hline \multirow{2}{*}{$\begin{array}{l}\text { MW } \\
\text { KDa }\end{array}$} & \multicolumn{4}{|c|}{ Peak area } & \multicolumn{3}{|c|}{ $\pm \%$ change of peak area with control } \\
\hline & $\begin{array}{l}\text { Susceptible } \\
\text { strain }\end{array}$ & $\begin{array}{l}\text { Fenpyroximate } \\
\text { resistant strain }\end{array}$ & $\begin{array}{l}\text { Hexythiazox } \\
\text { resistant strain }\end{array}$ & $\begin{array}{l}\text { Chlorfenapyr } \\
\text { resistant strain }\end{array}$ & $\begin{array}{l}\text { Fenpyroximate } \\
\text { resistant strain }\end{array}$ & $\begin{array}{l}\text { Hexythiazox } \\
\text { resistant strain }\end{array}$ & $\begin{array}{l}\text { Chlorfenapyr } \\
\text { resistant strain }\end{array}$ \\
\hline 146 & 2328 & - & - & - & new band & - & - \\
\hline 144 & - & - & 3089 & - & - & - & new band \\
\hline 55 & 5664 & 3027 & 113870 & - & new band & new band & new band \\
\hline 54 & - & - & - & 5274 & disappeared band & disappeared band & disappeared band \\
\hline 53 & - & 5922 & - & - & - & new band & - \\
\hline 48 & 9166 & 3975 & 1053 & 16821 & 45.51 & 76.37 & -1278.83 \\
\hline 44 & - & - & 12761 & - & - & - & new band \\
\hline 42 & 95380 & 5555 & - & - & new band & new band & - \\
\hline 41 & - & - & 685 & - & - & - & new band \\
\hline 40 & - & - & - & 378 & disappeared band & disappeared band & disappeared band \\
\hline 39 & 83863 & - & 89345 & 3933 & -2032.29 & disappeared band & -2171.68 \\
\hline 40 & - & 5858 & - & - & - & new band & - \\
\hline 36 & - & - & - & 2926 & disappeared band & disappeared band & disappeared band \\
\hline 34 & - & 10805 & - & - & - & new band & - \\
\hline 35 & 68188 & - & 71027 & - & new band & - & new band \\
\hline 31 & 27549 & - & 20017 & - & new band & - & new band \\
\hline 32 & - & 59597 & - & 29969 & disappeared band & -98.86 & disappeared band \\
\hline 27 & 15056 & 18163 & 17528 & 7269 & -107.13 & -149.87 & -141.13 \\
\hline 24 & 17599 & 18368 & 18695 & 27135 & 35.14 & 32.31 & 31.10 \\
\hline
\end{tabular}


Table (2) showed that the protein band of $144 \mathrm{KD}$ MW. was not present in all tested strains as well as in marker protein. The protein bands of MW 116, 66, 45 and $25 \mathrm{KD}$ were found only in marker protein.

Comparing the protein banding pattern from fenpyroximate, chlorfenapyr and hexythiazox resistant strains with susceptible strain, it was found that the protein bands with MW (54 and $36 \mathrm{KD}$ ) appeared only in susceptible strain, while disappeared in the other tested resistant strains of $T$. urticae (Table 3 ).

The protein band with MW 44 KD appeared only in Hexythiazox resistant strain. The protein bands with MW 53 and $34 \mathrm{KD}$ were only found in fenpyroximate resistant strain of $T$. urticae, whereas such bands were not found in the other strains. The protein bands pattern with MW 146, 35 and $31 \mathrm{KD}$ were found only in hexythiazox and chlorfenapyr resistant strains of $T$. urticae; such result may indicate that the mechanisms of resistance strains are similar for both strains (Table 4).

From the above-mentioned results, it is suggested that such bands may include probably the protein enzymes of esterase and P450 mono-oxygenase (MO) as mentioned by Tomas Van Leeuwen et al. (2006). They showed that they both enzymes are responsible for increasing the resistance to chlorfenapyr in the two spotted spider mite $T$. urticae resistant strain. It was also clear from the above-mentioned results that the use of SDS-PAGE technique may be a good tool as a biochemical marker on identification of resistance of T. urticae to acaricides and sheds light on the protein patterns fractions in resistant strains of the two spotted spider mite.

\section{REFERENCES}

Avanzati, A. M.; Baratti, M. and Bernini, F. 1994. Molecular and morphological differentiation between steganacarid mites ( Acari: Oribatida). Biological J. Linn. Soc. 52: 325-340.

Enohara, E. and Amano, H. 1996. Simple method for discriminating six common species of red spider mites (Tetranychus) (Acari: Tertranychidae) in Japan. J. Appl. Ent. Zool. 40: 311-315.

Flexner, J. L.; Westigard, P. H.; Hilton, R. and Croft, B. A. 1995. Experimental evaluation of resistance management for the two spotted spider mite (Acari: Tetranychidae) on southern Oregon pear: 1987-1993. J. Econ. Entoml.,
8:1517-1524.

Goka, K. and Takafugi, A. 1997. Identification among seven species of spider mites (Tetranychus) (Acari: Tertranychidae) based on enzyme differentiation detected by electrophoresis. Appl. Ent., Zool. 32: 127-134.

Ioriatti, C.; Sofia, M. and L. Menapace. 2000. Evaluation of the susceptibility of different strains of Panonychus ulmi to three M.E.T.I. acaricides (fenazaquin enpyroximate tebufenpyrad) and to propargite [Malus pumila Mill. - Trentino -mitochondrial electron transport inhibitor]. Atti-delle-Giornate-Fitopatologiche (Italy). pt. 1: 373-380.

King, J. and Lafmmili, U. K. 1971. Polypeptides of the tail fibers of Bacteriophage T4. J. Mol. Biol. 62: 465-477.

Laemmili, U. K. 1970. Cleavage of structural proteins during assembly of the head Bacteriophage T4. Nature, 277: $680-685$.

Lewontin, R. C. 1991. Electrophoresis in the development of evolutionary genetics: milestone or millstone. Genetica 128: 657-662.

Navajas, M. and Fenton, B. 2000. The application of molecular markers in the study of diversity in acarology. Exp. Appl. Acarol. 24: 751-774.

Navajas, M.; Tsagkarakou, A.; J. Lagnel and Perrot-Minnot, M. J. 2000. Genetic differentiation in Tetranychus urticae (Acari: Tetranychidae): polymorphism, host races or sibling species, Exp. Appl. Acarol. 24: 365-376.

Osakabe, M. and Komazaki, S. 1996. Differences in esterase isozymes between Panonychus citri populations infesting citrus and Osmantus. Exp. Appl. Acarol. 20: 113-119.

Smrz, J. 2000. Some soil fauna groups as a tool for soil characteristics analysis. IUAPPA Praha: Section A: 22-24.

Solomon, M. G.; Muray, R. W. and Van Der Geest, L. P. S. 1985. Analysis of prey by means of electrophoresis. Spider mites, their biology, natural enemies and control. Exp. Appl. Acarol. 2: 171-173.

Van Leeuwn, T.; Pottelberge, S. V. and Tirry, L. 2006. Biochemical analysis of chlorfenapyrselected resistant strain of Tetranychus urticae Koch. Chmelarstvi. 73: 4, 41-43.

Weber, K. and M. Osborn, M. 1969. The reliability of molecular weigh determination by sodium dodecyl sulfate polyacrylamide gel electrophoresis, J. Bio Chem. 244: 4406-4412.

Yasui, Y. 1997. Sperm competition and the significance of female multiple mating in the predatory mite Parasitus fumetorum. Exp. Appl. Acarol. 21: 651-664. 
